\section{Cultural significance of primary teeth for caregivers in Northeast Brazil}

\author{
O significado cultural dos dentes decíduos para \\ cuidadoras no Nordeste do Brasil
}

\author{
${ }^{1}$ Centro de Ciências da \\ Saúde, Universidade de \\ Fortaleza, Fortaleza, Brasil. \\ 2 Department of Social \\ Medicine, Harvard University \\ Medical School, Boston, \\ U.S.A. \\ 3 Universidade Estadual do \\ Ceará, Fortaleza, Brasil. \\ ${ }^{4}$ Coordenação Municipal \\ de Saúde Bucal, Fortaleza, \\ Brasil. \\ Correspondence \\ P. G. Calvasina \\ Universidade Estadual do \\ Ceará. \\ Rua Joaquim Nabuco 455, \\ apto. 403, Fortaleza, CE \\ 60125-120, Brasil. \\ paolacalvasina@yahoo.com.br
}

\begin{abstract}
This anthropological study critically evaluates Brazilian caregivers' symbolic production and significance of their malnourished offspring's primary teeth, as well as their own, and describes popular dental practices. From January to June 2004, ethnographic interviews of 27 poor, lowliteracy mothers were conducted at a public Malnutrition Treatment Center in Fortaleza, Ceará State. Participant observation of clinical pathways and home environments supplemented the data. Content analysis was performed. Results confirm that primary teeth are imbued with cultural significance in Northeast Brazil. Mothers examine mouths, perceive signs of decay, associate primary with permanent tooth healthiness, identify ethnodental illnesses, seek assistance, and perform rituals with exfoliated teeth. The mother's motivation to care for primary teeth is sparked by her memories of past toothache and attempts to avoid stigma and discrimination. Social determinants, not mothers' beliefs or behaviors, are the most critical obstacles to effective dental care. Legitimizing lay knowledge and empowering caregivers and children can improve oral health in Northeast Brazil.
\end{abstract}

Deciduous Tooth; Maternal Behavior; Cultural Anthropology
Marilyn K. Nations 1,2

Paola Gondim Calvasina 3,4

Michele N. Martin 1

Hilma Fontenele Dias 1

\section{Introduction}

Decay of primary or "milk teeth" [dentes de leite] is a pressing public health problem among Brazilian children living in poverty $1,2,3$. A recent nationwide epidemiological survey 4 , revealed that, on average, a Brazilian child under three years old has just over one tooth decayed (ceo- $\mathrm{d}=1.1$ ). At age five, the average increases to almost three teeth with caries (ceo- $d=2.8$ ). The high caries rate is not surprising given the negative association between the Human Development Index (HDI-M) and levels of dental disease in permanent and primary teeth 5,6. Baldani et al. 7 report a significant correlation between CPO-D/ceo-d and income inequality, linking children's caries experience to socioeconomic conditions. Pattussi et al. 8 identified social deprivation, income disparities, and social corrosion as responsible for differences in caries distribution. In the impoverished Northeast, where the HDI-M plummets to Brazil's lowest 5 , the malnutrition rate is $6.6 \%$, high by international standards $(2.5 \%){ }^{9}$ and oral disease is more severe; the ceo- $d$ reaches 3.21 in children five years or younger. Here, hunger and malnutrition are rampant $10 ; 84.4 \%$ in the 12-24-month age group were malnourished in 2002 in Fortaleza, Ceará State, according to the Health Department's household nutrition survey. Moreover, protein-calorie malnutrition is associated with delayed eruption of primary teeth and increased dental caries in children 11,12. Hunger, 
coupled with food shortage, stimulates exaggerated sugar consumption. Yearly sugar intake of Brazilians is $51.1 \mathrm{~kg}$ compared to $18.6 \mathrm{~kg}$ worldwide ${ }^{13}$. In order to "trick the belly into thinking it has food", deaden hunger pains, and halt crying, manioc mush, milk formulas, coffee, and juices are heavily sweetened, homemade pacifiers are fashioned by knotting sugar in a cloth diaper, rubber pacifiers are dipped in sugar, and inexpensive, high-calorie cookies, candy, and chunks of brown sugar [rapadura] are customarily fed to children 14,15 . As recently as 2004 , a study on health care service utilization in Brazil showed that only $18.1 \%$ of children under five years had gone to a dentist at least once in their lifetime 4 .

In their article An Ethnographic Study for Understanding Children's Oral Health in a Multicultural Community published in 2001, Riedy et al. 16 concluded that high rates of childhood dental caries in five ethnic populations on the Island of Saipan, Commonwealth on the Northern Mariana Islands, USA, were due to two key factors: mother's lack of appreciation and ambivalence towards the child's decayed primary teeth; and mother's own negative experiences with dental problems. Although the authors clearly state that system-level factors - societal, environmental, and cultural, etc. - are important determinants of oral health, they conclude that only maternal factors - health beliefs, attitudes, and knowledge and oral health behavior - are responsible for high caries incidence across the five ethnic groups.

The relative role that individual cognitive factors versus macro-sociological forces play in shaping human behavior cuts to the core of anthropological theory and debate since the 1960s 17,18, including in Northeast Brazil. Here, Scheper-Hughes 19 explains high infant mortality rates as due to poor mothers' so-called "selective neglect" and lack of motivation to save their infants' young lives. Nations \& Rebhun 20 counterargue that if "neglect" exists in this economically deprived setting, it is more of poor mothers by an uncaring medical and political system. What, then, can be inferred about the impact of maternal behavior on children's health outcomes? Nations \& Rebhun's 20 critique of mother-neglect theories in Northeast Brazil raises serious doubts about the conclusion by Riedy et al. 16 (p. 305) that mothers' dental-related beliefs and behaviors are "serious obstacles to be addressed in order for any new program to be effective".

This qualitative, anthropological inquiry investigates the symbolic construction of poor, Brazilian caregivers (mothers) regarding the primary teeth of malnourished offspring and popular dental practices. We aim to link individual-level factors with system-level determinants of oral disease in infancy and early childhood. Contrary to Riedy et al. 16, we argue that lay caregivers recognize and treat ethnodental diseases in infancy, that "milk teeth" (baby teeth) are imbued with cultural significance and ritualistic value, and that past toothache and problems motivate poor mothers to seek dental care for children, rather than deterring them from doing so, despite serious structural obstacles in Northeast Brazil.

\section{Methodology}

Utilizing a critical 21 , interpretative 22 approach, this ethnographic study aims to shift the biomedical focus from nutritional and dental pathology to the human experience of sick and hungry children. From January to June 2004, in-depth, ethnographic interviews were conducted with 27 mothers of malnourished children (between 2-72 months). Key informants were selected randomly from walk-in patients and statewide referrals at a public Malnutrition Treatment Center in Fortaleza (population 2.5 million) in Northeast Brazil. After triage by multidisciplinary professionals, cases are treated in the outpatient clinic, admitted, or transferred to a local hospital, depending on severity.

Participating mothers were young, $70.3 \%$ between 17 and 30 years of age, while the other $29.7 \%$ were $31-48$ years old. Most $(81.5 \%)$ were married or lived with fixed partners. Most of these women $(70.3 \%)$ had more than two children. Half (50\%) admitted suffering physical violence by "husbands", $9 \%$ of whom were unemployed. While $18.6 \%$ were separated or single mothers, most (85.2\%) were housewives with fixed income or unemployed; three (11.1\%) begged for spare change on city streets to "earn a crumb to feed my kids!". Only $14.8 \%$ worked outside the home, all (100\%) in manual, low-paying jobs like domestic, seamstresses, and laundresses; $100 \%$ earned less than the required minimum wage (US\$ 182.60/ month) (exchange rate $07 / \mathrm{Feb} / 2007$ ) without workers' benefits. Most (66.7\%) had less than five years of schooling, and $14.9 \%$ were illiterate. Children's average age was three years, with $43.8 \%$ boys and $56.5 \%$ females. Nearly one-half (47.8\%) of the youngsters presented severe malnutrition.

To reveal the cultural meanings attributed by caregivers to primary teeth, illness narratives 23,24,25,26 were conducted permitting free expression and interpretation of ideas and concepts. Participant observation was conducted throughout the children's clinical pathway and in three patients' residences. All observations were re- 
corded in a field notebook and contextualized and validated with ethnographic and narrative data $27,28,29,30$.

Narratives were transcribed completely in a text editor. After repeated readings, emerging units of meaning were identified and empirical categories constructed 25,31. Data were interpreted against a theoretical backdrop in medical anthropology. The study conformed to all Brazilian National Ethical Standards. All names cited are fictitious.

\section{Results}

Despite limited years of schooling (mean five years) and high illiteracy (14\%), poor Brazilian mothers value primary or "milk teeth", aware of their importance for children's health, even among sickly, malnourished offspring. Mothers such as Tânia, 30 years old, a grade school dropout and housewife with two malnourished children, curiously examine "what's inside" the child's mouth: "I always wanted to poke around inside to see if everything was okay (...) I even wanted that little mirror-tool for me to look around inside. Looking here, from the outside, everything seems fine, but inside it is more difficult to grab hold of the child's mouth (...) she won't let me. I'm very curious to know what's inside there".

Besides examining the mouth, mothers perceive diverse signs and symptoms of dental disease. Leda, an 18-year-old, unemployed, single mother with only five years of schooling eagerly tells of taking her 12-month-old son with moderate malnutrition to the dentist. "I went to the dentist to see how his mouth was (...) The dentist even showed me that there was no hole [cavity] or tooth turning black". Without saying the term "dental caries", mothers readily distinguished decayed from healthy teeth, albeit referring to them in popular language as "rotten" [pôdi], "spoiled" [estragado], or "eaten" [comido] teeth, among other terms. On the other hand, a child's healthy mouth is "full of white, clean teeth without any rotten ones (...) teeth without any little spots, a reddish-colored tongue and lips that aren't cracked and dried". The telltale test of a healthy mouth, say mothers, is a child who "doesn't suck a pacifier!". Symptoms of a "sick mouth" are also promptly recognized: "red, fowl-smelling, stinky mouth", with "thick, foaming spit lodged in the corners", "too much drool", "dry lips", "white tongue", and "yellow, spotty, or black teeth." When children "can't bite down or chew because it hurts their teeth," it is also a sign of alert. The phrases between quotation marks are not the words of a single, identifiable informant, but a synthesis of cultural meanings about primary teeth expressed by various informants in their illness narratives and grouped together for reporting purposes. It is a descriptive collection of symptoms, and it is thus logistically unfeasible to identify a particular informant for each symptom mentioned.

Mothers recognize that primary or "milk teeth" have a direct link to the health of permanent teeth. Caries-causing "tooth worms" [lagartinha] are popularly believed to pass not only from decayed permanent teeth to neighboring healthy ones, but the feisty, insatiable worm also boroughs its way downward into the gum, attacking deciduous teeth that have still not erupted; the infant "is already born with rotten teeth". The "tooth worm" can also pass, mothers say, from lower to upper teeth, requiring special attention and care. "You have to treat (...) to fix his teeth, otherwise they'll just start turning yellow (...) rotting (...) rotting and spoiling. At first it's only on the bottom teeth. Later, I think it passes to the ones on top! (...) It's important to start caring for your kids' teeth when they're still little" (Sandra, 23 years).

Despite their low literacy, mothers readily recall instructions on how to care for primary teeth, remembering the period to initiate brushing, frequency of brushing, and oral hygiene products. While mothers do not agree on one single moment to start caring for infant's teeth, several state that care should begin at birth: "From the moment the baby is born, the mother must clean its mouth". Others gage the introduction of toothbrushing according to developmental milestones: "when milk teeth break through the gums", "their little mouth is full of teeth", or "they start to eat things". Or, according to the child's chronological age: "from six months on", "beginning at one year, you can already start attacking the dirtiness", "early, right away at two years", or "from three years on". The latest period our 27 informants mentioned to start caring for teeth was five years of age. Still others insist on the best brushing frequency - "you have to brush after eating, brush all the time" - and recommend the appropriate product: "you have to tell him [the child] to brush with toothpaste and clean with fluoride so their teeth don't rot!".

Oral health is so important to infant survival that local culture, along with and its ethnomedical system, has created a specific folk illness, sapinho (literally "little frog"; see "thrush") to ensure that caregivers scrutinize the newborn's mouth. Mothers, grandmothers, and traditional healers [rezadeiras] are always on the alert for the sudden appearance of the "danger sign" of sapinhowhite dots (oral candidiasis) on the inside of the mouth, tongue, and throat, caused, according 
to popular belief, by breast milk sticking to the mucosal surface. Sapinho is especially feared in very poor, malnourished, and sickly infants. The "white dots" are said to spread quickly, invade the mouth's interior, restrict the air passage, and kill the baby. Our poor informants fear sapinho and go to extraordinary lengths to monitor subtle changes in their infant's mouth, preventing this dangerous folk illness. Socorro, 32, unemployed, married and mother of three children, carefully describes her home remedy for preventing sapinho. "If the mother doesn't clean that white off the baby's tongue after she breastfeeds, it causes a 'mouth disease' people call 'sapinho' (...) Since there is no way I want my children to get this disease, I take the tip of the baby's diaper or roll a ball of cotton around my finger and rub [sodium] bicarbonate in the mouths of all three (...) cleaning their teeth, mouth, and tongue. Some people claim I'm crazy, but it's to prevent problems in the future!". If Socorro notices something strange or different, she goes for help. "I open their mouth and look inside. If there's anything wrong I take them to the clinic right away".

A second folk illness, dentição or "teething", likewise directs caregivers' critical attention to oral abnormalities during infancy and childhood. Popular culture recognizes the "teeth cutting" period as particularly hazardous. Risk of diarrheal diseases increases in poor households without basic sanitation, where infants gnaw on contaminated objects to sooth swollen, aching gums. Dentição provokes fussiness, fever, and bloody diarrhea with mucous. Because mothers believe that no medicine should be given until the tip of the "milk tooth" breaks through the gums (lest it "recoil and kill the child"), they anxiously fix their attention on swollen gums, anticipating the moment when the intestinal infection can finally be treated.

The "teething" period, even without deadly dentição diarrhea, is a time when caregivers mobilize to relieve their infants' toothache. Cheap over-the-counter medicines like One Minute and Stop-Now are purchased and applied to aching gums. Cloves are ground up and rubbed on with the fingers to alleviate throbbing pain. Poor families also rely on the local folk healer [rezadeira], lay dentist [prático], and professional dentist.

Folk culture in Northeast Brazil not only values oral health during breastfeeding and the cutting of "milk teeth" during infancy, but continues to ascribe prestige to primary teeth even after they have fallen out, opening the way for permanent dentition. According to cultural tradition, rituals are practiced to ensure "good luck" and "birth" of healthy permanent teeth. While reciting out loud the lyrical folk verse, "Morão, Morão pega esse dente e me dá um são" ("Morão, Morão take this tooth and give me a healthy one"), the child throws the exfoliated "milk tooth" on top of the tile-roofed home. Others transform the solitary "milk tooth" into an amulet by perforating a small hole in the tooth and hanging it on a red string around their neck as protection against the evil eye.

Given past painful experiences with dental illness, the mothers we interviewed tried to avoid "tooth rotting" [dente estragado] in their children's "milk teeth" to spare them from similar suffering. Neide, 26, unemployed and living with an alcohol-dependent partner, states: "When I grew up, my mother never took care of my teeth, understand? But I think it's important (...) We have to take care of our own children. We know how it is and we have to take care (...) from the time she is little until she grows up big and can take care of her own teeth". Despite the many hardships of daily life, Helena keeps her son's teeth healthy by periodically taking him to the dentist. Her strong motivation to care for his teeth comes from memories of her own pain and frustration. "What we went through, we certainly don't want for our children". Determined to avoid the suffering she experienced as a youngster, another mother, Diana, 28, pleads with the clinic receptionist to set a dental appointment for her son. "Hey, woman, set a time for my little boy (...) I'm so scared his teeth will end up like mine - all rotted out. Just remembering my aching teeth, I was moved to tears (...) so I brought him to the dentist".

Discriminated against because of their "rotten teeth", mothers say they do not want their children to be humiliated in the same way. To keep the child from being teased as a "snagtooth" [banguela], they make personal sacrifices - within their meager means - to improve their children's appearance. Roberta, 37, who left her husband because he threatened her physically, supports her five children as a laundress. Despite her work overload, she finds time in her tiring schedule to care for her son's teeth. "I never had anyone to teach me, to help me take care of my teeth (...) But even so, I thought, I'm going to take care of him (...) You should see my boy's teeth, they're so pretty! One tooth was starting to rot, so I took him to the hospital (...) and I ordered them to examine everything. And, guess what? His teeth were perfect (...) just that tiny cavity. So they filled it, and it's great. Everyone thinks his teeth are beautiful, really beautiful (...) really natural".

Years later, Debora, 32, unemployed, married, and mother of a four-year-old daughter with moderate malnutrition, recalls the deep shame her "rotten teeth" caused her as a young girl: "If someone had taken care of me when I was a child, 
I wouldn't have suffered so much from toothache or embarrassment (...) I was ashamed to smile, because my teeth weren't white like my friends, who weren't afraid of going to the dentist with their mothers. I was afraid and had nobody to take me (...) But when I grew up, I started taking care of myself'. Marked with the scars of humiliation, like other mothers, Debora does not want the same fate for her own family. On the contrary, she wants "clean, white teeth - without fear or trauma" for her daughter.

Our informants are also subject to social pressure to care for their children's primary teeth. Neighbors, family, relatives, friends, and health professionals all comment, gossip, and criticize mothers of children with "rotten teeth". These women suffer twice - seeing their child discriminated against and being blamed for "letting their child's teeth get to this point!". Sandra, 23 , illiterate, unemployed, and single mother of four children, including a five-year-old boy with moderate malnutrition, complains of the social pressure she suffers: "People go around saying that his teeth are rotten, that I don't pay attention (...) always quick to scold, always giving their two cents worth, criticizing. But it's not my fault, no! I worry about his teeth rotting, believe me. The last time he was sick and hospitalized, they gave him iron sulfate and ruined his teeth - weakened and rotted them! Sure, I'm embarrassed by my friends' comments (...) that I have to treat his teeth because otherwise they'll turn yellow and start rotting, rotting, and rotting...”.

Difficult access to dental services in the city of Fortaleza, refusal by some dentists to treat young children, lack of physical infrastructure, dental instruments, and materials in public clinics, absence of an oral hygiene education and flouride program in schools are just a few factors that our informants reported as obstacles to accessing quality dental care. Given the difficulty in obtaining quick, efficient access to quality care and financial barriers to paying for private care, even for determined mothers it takes months to see a dentist, thus worsening the problem for children. As a result, the children present to dentists with advanced decay. Marisa, 30, unemployed, married, with a five-year-old daughter with moderate malnutrition, laments: "It's terribly painful for a mother to see her daughter with teeth this way (...) a bunch of her 'milk teeth' rotten (...) the ones in the back with huge holes (...) I don't know if she is skinny because of these awful teeth (...) I see no other reason. If I had the money, I would pay anything not to see her teeth like this!". Despite constraints, mothers generally seek dental care - either popular or/and professional - when they perceive something wrong with the child's teeth.
Some even take their children for routine checkups to prevent cavities.

However, the response from health providers is not always comforting or efficient. Long lines, rationed appointments, professional absenteeism, broken equipment, energy blackouts, and staff strikes are structural constraints that bar children from dental care in our setting. Poor parents often lack not the will, but the way, to obtain dental care for children. During most of their infancy, Marisa - living with her two children in a crowded, three-room, brick tenement in one of Fortaleza's more than 300 urban slums - left home before daybreak with her two children tagging behind, walking through dangerous city streets, then waiting in line until dawn at the dental clinic, only to be turned away. Today, her frail six-year-old daughter's teeth are being repaired while treating her underweight at the malnutrition center. Using a cousin's address, she takes her son to a free university dental service available to neighboring families: "She sometimes stopped eating because her tooth hurt (...) and we didn't have enough money to take her to a dentist (...) I used to take her in my arms, walk to the clinic (...) sleep all night on line just to get an appointment (...) but when I woke up, she was crying and the appointments quota had run out (...) I just stopped going to the clinic".

Even persistent mothers like Cleide, 26, who finally obtained care for her two-year-old boy suffering from malnutrition and two decayed primary teeth, are discouraged by dubious medical "advice" from attending health professionals: "My boy has two rotten milk teeth, so I took him to the clinic (...) the dentist told me to just leave it alone (...) that this thing [milk teeth] just rots, then afterwards a normal tooth sprouts". Dentists can underrate the importance of healthy primary teeth, thus negatively influencing mothers' attitudes and actions.

\section{Discussion}

Contrary to the findings by Riedy et al. 16, Brazilian caregivers (mothers) were found to value primary or "milk teeth", which hold particular cultural significance for children's oral health. While mothers in our ethnographic study have far less formal education - an average of only five years of schooling - as compared to 12 years among five ethnic groups in the Mariana Islands - they nevertheless present ample evidence of prioritizing their offspring's primary teeth. This was true even for malnourished children. Mothers we interviewed in poverty-stricken Northeast Brazil examine the child's mouth, identify signs 
and symptoms of dental problems, characterize healthy-looking teeth, self-treat "rotten teeth", and seek folk healers and professional dentists to relieve their child's toothache. Ethnographic studies by medical anthropologists confirm that in response to perceived health threats, cultures evolve their own ethnomedical systems to combat suffering, disease, and death. Such lay systems are complex, with their own explanatory models of disease 23,32,33 etiological notions 34,35 ethnoanatomical conceptualization 36,37,38,39, medicines 40 , treatment rituals 41,42 , and prevention strategies 43 . Such a vibrant ethnomedical system has been described in Northeast Brazil 19,20,41,44, including an ethnodental system 15 .

If, indeed, Brazilian caregivers did not value their children's primary teeth, there would be no evidence of popular terminology referring to "milk teeth", diagnostic signs and techniques, and folk dental illnesses of infancy and early childhood like dente estragado, sapinho, or dentição, or traditional healers to pray on aching teeth or folk remedies to ease pain. We see no "ambivalence" toward decayed primary teeth, as reported in the Mariana Islands by Riedy et al. 16. While the five ethnic groups reached no consensus, many parents reportedly "did not like to see cavities in their children's teeth, but did not feel that the decayed teeth should be repaired" 16 (p. 308), waiting until the teeth fall out, whether decayed or not. Rather, our informants proved to be interested in their children's oral health and actively sought care, albeit frequently within the popular and folk sphere 23 .

If primary teeth held no value in Northeast Brazil, it would make no sense to create and perform a ritual with exfoliated "milk teeth" - symbolizing good luck - to guarantee the "birth" of healthy permanent teeth. According to the classic anthropological theory of Malinowski 45, human cultures ritualize behavior as a means to control - at least symbolically - the uncertainty, anxiety and fear surrounding certain events whose outcome is unpredictable. If, indeed, primary teeth were "worthless" there would be no reason to go to such great lengths to save lost "milk teeth", recite prayers to "Morão", throw "milk teeth" on rooftops, or wear them as lucky tooth-pendants to ward off the evil eye. On the contrary, primary teeth hold rich symbolic importance for poor Brazilians.

Reasons cited by Riedy et al. 16 for irregular dental visits were cost, lack of dental insurance, and fear, contending that such past negative experiences are the primary motivators for mothers' "ambivalent" attitudes toward dental care. For our informants, past negative experiences were associated not with financial problems, but with pain, suffering, humiliation, and discrimination provoked by their "rotten", decaying teeth. According to Nations \& Nuto 15 , tooth decay, abscesses, peridontal disease, missing teeth, and poorly-fitted dentures announce patients' low social status, stigmatizing them as "poor", "marginal", and "unwanted". Contrary to Saipan mothers, avoiding such "past negative experiences” strongly motivated impoverished Brazilian mothers to seek dental care for their children in order to spare them from the same suffering.

Riedy et al. 16 concluded that adverse parental experience and disregard for primary dentition are serious obstacles to the effective implementation of any new dental program. They identified cognitive factors - perceptions, attitudes, and beliefs - of mothers as responsible for children's poor oral health. Sociologist Ryan 46 characterizes such psychologically-minded explanations as "victim-blaming", since the locus of responsibility for negative health outcomes is placed squarely on the shoulders of those who most suffer its consequences. Our study, by contrast, underscores the critical influence of system-level factors and structural constraints that impinge on caregivers' lives and restrict poor families' opportunity and access to quality dental care. Many factors beyond mother-blaming ambivalence - low income, long lines, rationed appointments, broken equipment, faulty materials etc. - make it difficult to care for primary teeth, irrespective of mothers' motivation. To speak of maternal lack of interest in Northeast Brazil is unjustified as an explanation of children's poor oral health. If any ambivalence exists, it is perhaps not practiced by lay caregivers but perpetuated by an unjust and precarious public dental health system.

\section{Conclusion}

Based on this ethnographic study, we reveal the cultural value and significance that poor Brazilian caregivers (mothers) ascribe to their malnourished children's primary teeth. Attributing poor oral health to mothers' devaluation of primary dentition or past negative experience may contribute unjustly to mother-blaming interpretations. Mothers in Northeast Brazil have the will, but not the way, to treat their offspring's teeth. Macro-sociological forces - poverty, hunger, sugar-heavy diets, access barriers, and poorly structured dental services - are overwhelmingly responsible for tooth decay and loss. Like mothers, popular culture with its ethnomedical system mobilizes scarce resources to relieve toothache. Humanizing dental care requires that profes- 
sionals adopt a critical stance in order to value lay health knowledge and action, identify social de- terminants of oral suffering, and confront health care inequalities.

\section{Resumo}

Este estudo antropológico analisa a produção simbólica de cuidadoras brasileiras sobre a sua dentição e a de seus filhos desnutridos, descrevendo práticas populares de cuidados em saúde bucal. De janeiro a junho de 2004, foram conduzidas entrevistas etnográficas com 27 cuidadoras, numa instituição pública, no tratamento de desnutrição em Fortaleza, Ceará. A observação participante da dinâmica de atendimento $e$ do ambiente domiciliar suplementaram os dados. Foi utilizada a análise temática. Os resultados confirmam que os dentes decíduos são imbuídos de significados culturais no nordeste brasileiro. As mães examinam as bocas dos filhos, percebem sinais de cárie, associam dentes decíduos saudáveis com permanentes hígidos, identificam enfermidades etnodentárias, procuram assistência e praticam rituais com dente decíduo esfoliado. A motivação das mães para o cuidado com dente decíduo é envolvida por experiências de dor de dente e tentativas de evitar estigma e discriminação. Dificuldades de acesso, serviços precários, pobreza e desigualdade social colocam em risco a saúde bucal das crianças e não crenças e comportamentos maternos. A legitimação do conhecimento de cuidadoras e seu empoderamento podem melhorar a saúde bucal no nordeste brasileiro.

Dente Decíduo; Comportamento Materno; Antropologia Cultural

\section{Contributors}

P. G. Calvasina collected that data, contributed to the analysis, and revised the article. M. K. Nations participated in the organization of the article and contributed to the analysis, methodology, and drafting of the article. M. N. Martin and H. F. Dias collaborated in the organization and drafting of the article.

\section{Acknowledgments}

The authors wish to the thank the Conselho Nacional de Desenvolvimento Científico e Tecnológico [CNPq, Brazilian National Research Council] for the scientific initiation scholarships granted to Michele N. Martin and Hilma Fontenele Dias and the post-doctoral scholarship granted to Marilyn K. Nations. We also would like to thank Fundação Cearense de Apoio ao Desenvolvimento Científico e Tecnológico [FUNCAP, Ceará State Research Foundation] for the financial support to Paola Gondim Calvasina, during her master degree. 


\section{References}

1. Cardoso L, Rössing C, Kramer P, Costa CC, Costa Filho LC. Polarização da cárie em municípios sem água fluoretada. Cad Saúde Pública 2003; 19:237-43.

2. Ribeiro AG, Oliveira AF, Rosenblatt A. Cárie precoce na infância: prevalência e fatores de risco em pré-escolares, aos 48 meses, na cidade de João Pessoa, Paraíba, Brasil. Cad Saúde Pública 2005; 21:1695-700.

3. Weyne SC. A construção do paradigma de promoção de saúde: um desafio para as novas gerações. In: Kriger L, organizador. ABOPREV: promoção de saúde bucal. São Paulo: Editora Artes Médicas; 2003. p. 1-23.

4. Departamento de Atenção Básica, Secretária de Atenção à Saúde, Ministério da Saúde. Projeto SB Brasil 2003: condições de saúde bucal da população brasileira 2002-2003. Resultados principais. Brasília: Ministério da Saúde; 2004.

5. Antunes JLF, Peres MA, Mello TRC. Determinantes individuais e contextuais da necessidade de tratamento odontológico na dentição decídua no Brasil. Ciênc Saúde Coletiva 2006; 11:79-87.

6. Peres MA, Peres KG, Antunes JLF, Junqueira SR, Frazão P, Narvai PC. The association between socioeconomic development at the town level and the distribution of dental caries in Brazilian children. Rev Panam Salud Pública 2003; 14:149-57.

7. Baldani MH, Vasconcelos AG, Antunes JLF. Associação do índice CPO-D com indicadores sócioeconômicos e de provisão de serviços odontológicos no Estado do Paraná, Brasil. Cad Saúde Pública 2004; 20:143-52.

8. Pattussi MP, Marcenes W, Croucher R, Sheiham A. Social deprivation, income inequality, social cohesion and dental caries in Brazilian school children. Soc Sci Med 2001; 53:915-25.

9. Monteiro CA, Conde WL, Konno SC. Análise do inquérito "Chamada Nutricional 2005" realizado pelo Ministério do Desenvolvimento Social e Combate à Fome e Ministério da Saúde. São Paulo: Núcleo de Pesquisas Epidemiológicas em Nutrição e Saúde, Departamento de Nutrição, Faculdade de Saúde Pública, Universidade de São Paulo; 2006.

10. Guerrant RL, Souza MA, Nations MK, editors. At the edge of development: health crises in a transitional society. Durham: Carolina Academic Press; 1996.

11. Alvarez JO, Eguren JC, Caceda J, Navia JM. The effect of nutritional status on the age distribution of dental caries in the primary teeth. J Dent Res 1990; 69:1564-6.

12. Psoter WJ, Reid BC, Katz RV. Malnutrition and dental caries: a review of the literature. Caries Res 2005; 39:441-7.

13. Narvai PC. Recursos humanos para a promoção de saúde bucal. In: Kriger L, organizador. ABOPREV: promoção de saúde bucal. São Paulo: Editora Artes Médicas; 2003. p. 447-63.

14. Monte C, Ashworth A, Nations MK, Lima A, Barreto A, Hutley SR. Designing educational messages to improve weaning food hygiene practices of families living in poverty. Soc Sci Med 1999; 44:1453-64.
15. Nations MK, Nuto SAS. Tooth worms, poverty tattoos and dental care conflicts in Northeast Brazil. Soc Sci Med 2002; 54:229-44.

16. Riedy CA, Weinstein P, Milgrom P, Bruss M. An ethnographic study for understanding children's oral health in a multicultural community. Int Dent J 2001; 51:305-12.

17. Foster GM. Peasant society and the image of limited good. Am Anthropol 1965; 67:293-315.

18. Valentine C. Culture and poverty: critique and counter-proposals. Chicago: University of Chicago Press; 1968.

19. Scheper-Hughes N. Culture, scarcity, and maternal thinking: maternal detachment and infant survival in a Brazilian shantytown. Ethos 1983; 13:291-317.

20. Nations MK, Rebhun LA. Angels with wet wings won't fly: maternal sentiment in Brazil and the image of neglect. Cult Med Psychiatry 1988; 12:141-200.

21. Singer M. The coming of age of critical medical anthropology. Soc Sci Med 1989; 27:25-38.

22. Geertz C. The interpretation of cultures. New York: Basic Books; 1973.

23. Kleinman A. Patients and healers in the context of culture: an exploration of borderland between anthropology and psychiatry. Berkeley/Los Angeles: University of California Press; 1980.

24. Lira GV, Catrib AMF, Nations MK. A narrativa na pesquisa social em saúde: perspectiva e método. Revista Brasileira de Promoção da Saúde 2003; 16:59-66.

25. Caprara A, Veras MS. Hermenêutica e narrativa: a experiência de mães de crianças com epidermólise bolhosa congênita. Interface Comun Saúde Educ 2004; 9:131-46.

26. Alves PCB, Rabelo MCM, Souza IM. Introdução. In: Rabelo MCM, Alves PCB, Souza IMA, organizadores. Experiência de doença e narrativa. Rio de Janeiro: Editora Fiocruz; 1999. p. 11-42.

27. Becker HS. Métodos de pesquisa em ciências sociais. São Paulo: Editora Hucitec; 1997.

28. Minayo MC. O desafio do conhecimento: pesquisa qualitativa em saúde. 7ạ Ed. São Paulo: Editora Hucitec/Rio de Janeiro: ABRASCO; 2000.

29. Gaskell G, Bauer MW. Pesquisa qualitativa com texto, imagem e som - um manual prático. Petrópolis: Editora Vozes; 2002.

30. Cliford J. A experiência etnográfica - antropologia e literatura no século XX. Rio de Janeiro: Editora UFRJ; 2002.

31. Ekman I, Ehnfors M, Norberg A. The meaning of living with severe chronic heart failure as narrated by elderly people. Scand J Caring Sci 2000; 14:130-6.

32. Nations MK. The child's disease (doença de criança): popular paradigm of persistent diarrhea? Acta Paediatr Suppl 1992; 381:55-65.

33. Good B. The heart of what's the matter: the semantics of illness in Iran. Cult Med Psychiatry 1977; 1:25-58.

34. Nations MK, Monte CMG. “I'm not dog, no!": cries of resistance against cholera control campaigns. Soc Sci Med 1996; 43:1007-24. 
35. Helman CG. "Feed a cold, starve a fever": folk models of infection in an English suburban community, and their relation to medical treatment. Cult Med Psychiatry 1978; 2:107-37.

36. Scheper-Hughes N, Lock MM. The mindful body: a proglomenon to future work in medical anthropology. Med Anthropol Q 1987; 1:6-41.

37. Snow LF. Folk medical beliefs and their implications for care of patients. Ann Intern Med 1974; 81:82-96.

38. Helman CG. The body image in health and disease: exploring patients' maps of body and self. Patient Educ Couns 1995; 26:169-75.

39. Paim HHS. Marcas no corpo: gravidez e maternidade em grupos populares. In: Duarte LFD, Leal OF, organizadores. Doença, sofrimento e perturbações: perspectivas etnográficas. Rio de Janeiro: Editora Fiocruz; 2001. p. 31-47.

40. Nations MK, Rebhun LA. Mystification of a simple solution: oral rehydration therapy in Northeast Brazil. Soc Sci Med 1988; 27:25-38.
41. Nations MK, Barreto AP. Culture, saints and cures in the Sertão. In: Guerrant RL, Souza MA, Nations MK, editors. At the edge of development: health crises in a transitional society. Duhram: Carolina Academic Press; 1996. p. 29-52.

42. McGuire MB. Ritual healing in suburban America. Piscataway: Rutgers University Press; 1988.

43. Agyepong IA. Malaria: ethnomedical perceptions and practice in an Adangbe farming community and implications for control. Soc Sci Med 1992; 35:131-7.

44. Nations MK, Misago C, Fonseca W, Correia LL, Campbell OMR. Women's hidden transcripts about abortion in Brazil. Soc Sci Med 1997; 44:1833-45.

45. Malinowski B. Magic, science, and religion. Boston: Beacon Press; 1984.

46. Ryan W. Blaming the victim. New York: Panthenon Books; 1971.

Submitted on 06/Mar/2007

Final version resubmitted on 24/Jul/2007

Approved on 30/Jul/2007 